\title{
PERSONAL CHARACTER, INSTRUCTIONAL, AND RESEARCH SKILL: CONTRIBUTION OF HIGHER EDUCATION TO THE HUMAN RESOURCE DEVELOPMENTS
}

\author{
Beta Romadiyanti \\ Master Program of Higher Education Management, \\ Graduate School of Universitas Gadjah Mada \\ Email: betaromi70@gmail.com
}

\begin{abstract}
igher education is one of the central of human resourses $\mathrm{H}$ improvement. Educators are one of the factors that determine the higher education quality. The purposes of this research are to explore how the character of higher education lectures affect the students and to see the condition of the lecturers skill and personal character in educating and researching at the Department of Health Policy and Management (HPM) of Gadjah Mada University. The methods that are used in this study was literature review and an online survey. The samples were 14 lecturers from HPM UGM. The ability and good personal character of lecturers in educating and researching will have a great impact on the learners. From this study it can be concluded that the HPM lecturers at Gadjah Mada University have the ability and good character in educating and researching.
\end{abstract}

Keywords: skill, educate, research, character, human resources

\section{INTRODUCTION}

The purpose of this paper are to explore how the character of higher education lectures affect the students, and to see the condition of the lecturers skill and personal character in educating and researching at the Department of Health Policy and Management (HPM) of Gadjah Mada University. Departement of Health Policy and Management is the member of the Medical Faculty of Gadjah Mada University. Gadjah Mada University is one of the biggest higher education in Indonesia.

The quality of educational system will be reflecting the graduates' quality and readiness for required skills (Soukalová, 2015). Higher educations are places to improve the human resources. Higher educations are the central of the knowledge, skill and behavior improvement. The academic and non academic curriculum provide a chance to the student to improve their ability. Higher education have the important role in the country, both developing or developed country.

Jung (2003) have found that education spending has the significant and positive relation with human capital and economic growth. Human capital is the economic term of human resources. This finding shows that education and human resource are closely related. Barro (2001) also described that education and humal capital affect the economic growth. This shows that educational is the most important factor of the country development. 
The most of the Indonesia leaders are the higher education products. The recent president and vice president of Indonesia, both of them are graduated by higher education. Political studies center of Universitas Indonesia released the Indonesian Representatives profil of education, that the representatives graduated 43,06 \% from undergraduate programs, 38,2 \% from master programs, $8,65 \%$ from doctoral programs, $8,47 \%$ from senior high school, and $1,62 \%$ from vacasional programs. This profil shows that $91,35 \%$ of the Indonesian Representatives are the higher education products. This phenomenon shows that how important higher education to produce the next Indonesian Leader.

Thomson (2008) described that commitment, capacity, and character are the core constructs of the worthy leadership. Characters of the leader are very important to affect the followers. Liborious (2014) also found that leader characters affect the follower perceptions. Lickona (1991) also stated that values and character are important to teach, these are the factors of the successfull democratic society.These are having the deep meaning, that Indonesian next leaders must have good characters to build their country. Education institution is one of the place that being the source of the knowledge, skill and character building. This paper will discuss how the character of higher education lectures affect the student.

Educators is the main power of education institutions. In higher educations, the lectures not just an educators but also researchers. Lectures in Indonesia have three main responsibilities, that are called tridarma, tridarma consist of educating, researching and serving to the community. As an educators, the lectures have the role as a leader at the class. So, the lectures abilities are very important and will affect the students. Levental (1977) founds that the lecturer quality affect the students achievement. There are several abilities that must be having by the lectures. Some of the abilities are researching skill, instructional skill, and good personal character.

Braxton (2000) found that the lecturer's teaching skills are influencing the students, with direct and indirect effects. Lecturer's instructional skill give the impact on the effectiveness of learning process. The lecturer need to have not only teaching skill bu also researching skill. Lecturers's research skill influence their teaching (Prince, 2007). This is actually related with the student's tesis or research requirement to be graduated. Classes that are took by students will support their research at the future. So, the lecturers need to have both teaching ang researching skill. And how about lecturer's character? This study will discuss about how the character of higher education lectures affect the students.

\section{Methods}

This research using both literature review and online survey. These methods are used to find the purposes of the research. Literature review is used to explore how the character of higher education lectures affect the students, and online survey is used to see the condition of the personal character and lecturers skills in educating and researching at the Department of Health Policy and Management (HPM) of Gadjah Mada University.

Researcher is using literature review to find out how the character of higher education lectures affect the students. Literature review must be relevan and effective. Literature review is the way to prepare future by using of past 
results ( Webster, 2002). In the education field, literature review are still common use by the educational researcher.

The literatures that are used must be related with the topic. In this paper we will discuss about how the lecturer character will affect the student. There is no requirement for the author of literature, so every literature that match with the topic will be taken. The literature that is used are the literature from international jurnals and books that are related with the topic. The literature consist of research paper and the literature review articles and no year limitation.

Personal character of the lecturer in this research are the lecturer character that related with their job and position. The lecturer must have a capability, not only a educator but also a scientist in higher education. The lecturer also must represented the good personal character, both as an educator and as a scientist.

The lecturer skills actually have the wide meaning. The scopes of this study are the lecturer skill that related with their job, as an educators and a scientist. As an educator and a scientist, the lecturer must have the teaching skill and researching skill. The teaching skill and researching skill are the main skill or ability that the lecturer must have.

Online survey was used to see the condition of the personal character and lecturers skills in educating and researching. Online survey is choosen because online survey do not take time and more flexibel on the partisipant time to take the surveys. Online survey suitable to the busy partisipant. HPM lecturer are also a doctor. So they are a busy people.

The partisipants of the survey in this study are the lecturer of Department of Health Policy and Management (HPM) of Gadjah Mada University. Department of Health Policy and Management (HPM) UGM has 20 lecturers. The lecturer of this department mostly the member of the other departement too in Medical Faculty of Gadjah Mada University.

The Department of HPM UGM consist of master programs of Health Policy and Management. Health Policy and Management is a health science field study program that focuses on science policy and management in the health context. The objective of the master programs of Health Policy and Management is the creation of the profile the capabilities and characteristics of the graduates who can apply the principles of science policy and management of health, communicative competence, cultural competence, competence analytic / assessment, competency to create program / policy, competence planning and management financial, and competence to become a leader (leadership) and think the system framework (systems thinking).

The data that are collected from online survey are consist of quantitative data. The instrument used was a questionnaire that was developed based on the scientific leadership by Trisnantoro (2015). The quessionare that is used have been validated before using. The validation of the instrument are in the other group of lecturer in medical faculty of Gadjah Mada University. The data result will be analyzed using descriptive analysis of SPSS.

The quesstionare is the self assessment quissionare as an instrument. The quesstionare consist of personal character, teaching skill and researching skill. The quesstionare using the likert scale from 1 to 5 . The " 1 " have the meaning that too weak of character and skill and " 5 " have a meaning that too 
strong. The partisipant must assest their personal character, teaching skill and researching skill by giving checklist at the questionare.

\section{RESULTS AND DISCUSSION \\ Literature Review of Lecturer Character}

Researcher is using literature review to find out how the character of higher education lectures affect the students. The literature review will disscuss comprehensively about personal character, personal character that usually having by lecturer as a scientist and educators, and how that is should impact to the student.

Character is everything (Gough, 1997). Characters have big impact to everyone, especially for themself. Gough (1997) also studied that character can affect the promote of ethical excelence in sport. Our character will be shown to another people during interaction. The character structure of enemy were studied during the war (Haring, 1946). This study reflected that characters are very important and affect the strenght of the country.

Lecturers in higher education have responsibilities as an educators and as a scientist or researcher. Each responsibility has different scope and aspects. The character that must be shown at the each responsibility is different.

The scientist have the responsibilities to keep the virtue ethics (Chen, 2013). The virtue ethics actually the old scientist ethics. The personal character of the scientist will affect how they follow this etics. For the surveys that is found that scientist are lacking on immorality (Rutjens, 2016). There are several bad images about scientist. But as a lecturer, a scientist also an educators. So this is very dangerous. Because the lecturer not only a scientific leader in the laboratory but also a leader in the class. These are being the challenge to the lecturer how to be both good scientist and good educator.

Wayne \& Youngs (2003) studied about the teacher characteristics and student achievement gain. Educators are the main resource of the education system. The studies about educator characteristics are very important to make educational policies.

The educators quality affect the student experiences and outcomes (Rowe, 2003). The educators quality encompass a lot of aspect. Teaching skill, pedagogic skill, mastering of the material, and performance of an educator are related with quality. Barber (1992) predicted the white house performance using the president character. This is showing that the character can predict the performance.

Teacher and student relationships played important role in the education (Crosnoe, 2004). The communication and the relationship between the educator and their student are affect the student achievement. The teacher and student characters support this communication and relationship. The student achievement related with student motivation. Motivation may come from several sources, and learning environtment should affect the student motivation (Micthel, 1996). Student environment in school are complicated. Education institution mainly consist of teacher and students. The other students and teacher are the main environtment to the student.

Thweatt \& McCroskey (1998) tried to find out about the impact of the teacher behaviour on the student perceptiont of teacher credibility. As, the result, that the immediacy as the positive behaviour of the teacher have a 
positive effect to the teacher credibility. And the misbehaviour as the negative behaviour of the teacher have a negative impact to the teacher credibility. Credibility has positive affects toward teacher and student. The cognitive learning of the student is related with their perceptions on the teacher credibility.

From the literature review above we can find a model, how the educators character can affect the student, Figure 1 shows that. The lecturers character should affect the communication between educators and student. The lecturers character also can affect the student perception about the educators' credibility. Through that aspect, the educators character giving the impact to the students. The educators character should affect the students motivation and achievement.

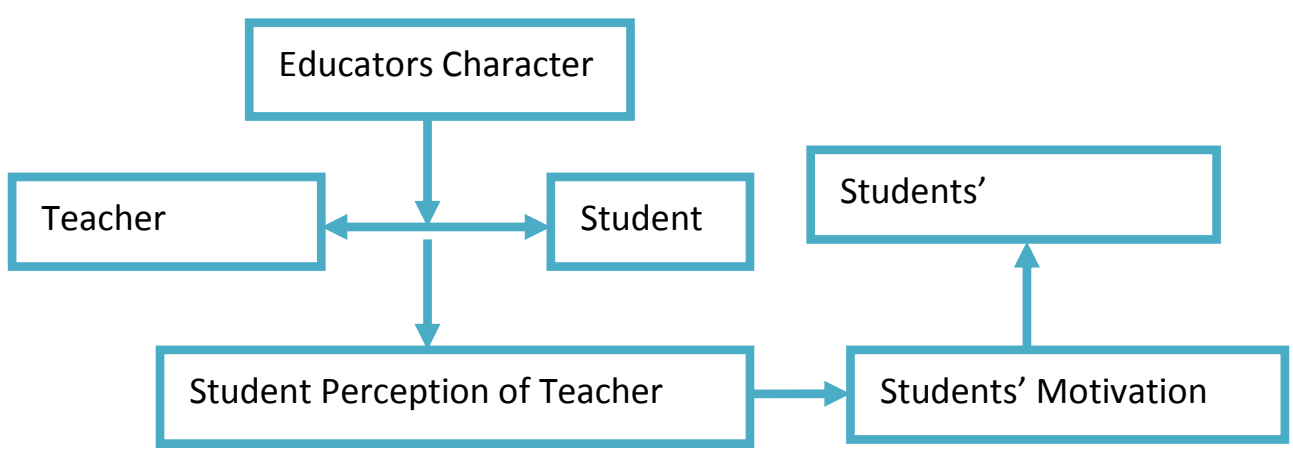

Figure 1

Online Survey of Department of HPM of Gadjah Mada University

The second purpose of this research is seeing the condition of the lecturers skill and personal character in educating and researching at the Department of Health Policy and Management (HPM) of Gadjah Mada University. Online survey was used to find that. The quesstionare was sent to 20 HPM's lecturers. There are 14 quissionare that are fullfilled and can be processed.

The collected data are analyzed by descriptive analysis of SPSS. Descriptive analysis are used in this research because of the data that are collected are in the likert scale of the self assesment. The variables will not find the correlation each other, so the descriptive analysis is enough. Tabel 1, Table 2 , and Table 3 show the result of the frequency descriptive analysis by using SPSS. Table 1 shows the teaching skill frequency. Table 2 shows the researching skill frequency. Table 3 shows the character frequency. The Table 3 rather different with Table 1 and Table 2, because, to measure character there are four items of question, different with teaching skill and researching skill.

Table 1 shows the frequency of the teaching skill that are having by the HPM's lecturers. That table shows that $71,4 \%$ lecturers state that they are have strong teaching skill by choosing mark 4 . Then, 14,3 \% HPM's lecturer choose mark 3 , it shows that they state that they have medium teaching skill. And the last $14,3 \%$ of them, choose 5 , or that is mean that they state that they very strong on the teaching skill. 
Table 2 shows the frequency of the researching skill that are having by the HPM's lecturers. That table shows that $64,3 \%$ lecturers state that they are have strong researching skill by choosing mark 4. Then, 35,7 \% HPM's lecturer choose mark 3, it shows that they state that they have medium researching skill.

\begin{tabular}{|c|c|c|c|c|c|}
\hline \multicolumn{6}{|c|}{ Table 1. Teaching Skill Frecuency } \\
\hline & & Frequency & Percent & $\begin{array}{c}\text { Valid } \\
\text { Percent }\end{array}$ & $\begin{array}{c}\text { Cumulative } \\
\text { Percent }\end{array}$ \\
\hline \multirow{4}{*}{ Valid } & 3 & 2 & 10.5 & 14.3 & 14.3 \\
\hline & 4 & 10 & 52.6 & 71.4 & 85.7 \\
\hline & 5 & 2 & 10.5 & 14.3 & 100 \\
\hline & Total & 14 & 73.7 & 100 & \\
\hline Missing & System & 5 & 26.3 & & \\
\hline \multicolumn{2}{|c|}{ Total } & 19 & 100 & & \\
\hline \multicolumn{6}{|c|}{ Table 2. Researching Skil Frecuency } \\
\hline & & Frequency & Percent & $\begin{array}{c}\text { Valid } \\
\text { Percent }\end{array}$ & $\begin{array}{c}\text { Cumulative } \\
\text { Percent }\end{array}$ \\
\hline \multirow{3}{*}{ Valid } & 3 & 5 & 26.3 & 35.7 & 35.7 \\
\hline & 4 & 9 & 47.4 & 64.3 & 100 \\
\hline & Total & 14 & 73.7 & 100 & \\
\hline Missing & System & 5 & 26.3 & & \\
\hline \multicolumn{2}{|c|}{ Total } & 19 & 100 & & \\
\hline \multicolumn{6}{|c|}{ Table 3. Character Frecuency } \\
\hline & & Frequency & Percent & $\begin{array}{c}\text { Valid } \\
\text { Percent }\end{array}$ & $\begin{array}{c}\text { Cumulative } \\
\text { Percent }\end{array}$ \\
\hline \multirow{7}{*}{ Valid } & 13 & 3 & 15.8 & 21.4 & 21.4 \\
\hline & 14 & 3 & 15.8 & 21.4 & 42.9 \\
\hline & 15 & 1 & 5.3 & 7.1 & 50 \\
\hline & 16 & 4 & 21.1 & 28.6 & 78.6 \\
\hline & 17 & 1 & 5.3 & 7.1 & 85.7 \\
\hline & 18 & 2 & 10.5 & 14.3 & 100 \\
\hline & Total & 14 & 73.7 & 100 & \\
\hline Missing & System & 5 & 26.3 & & \\
\hline \multicolumn{2}{|c|}{ Total } & 19 & 100 & & \\
\hline
\end{tabular}

Table 3 shows the frequency of the character that are having by the HPM's lecturers. To measure the lecturers character, there are four item of the questionare that are used. On the analysis we transform the variable first before analyzed by frequency. From table 3 we found that the range of the total skor of four item are from 13 until 18. That is mean that the average of each poin is 3,25 until 4,5 . Or that is mean that the lecturers mosly state that they have strongly good character.

Compared to the three tables above, we can see that the lecturers mostly confident in the teaching ability. Lecturers who claimed that they have the teaching skill in medium even less than 15 percent. This fits in with the main responsibilities of the lecturer as an educators. But, if we look at the overall, 
majority lecturers stated that have strong in the ability to teach, research, as well as personal character.

These results show that the HPM's lecturer assess theirself and state that they have a strongly good capacity as an educators. The results show that the lecturers are confident with their ability and character. That is very important as an educator. Because the confidence give an impact to the performance (Woodman, 2003).

\section{CONCLUSION, RECOMMENDATION, CONTRONTRIBUTION}

The purposes of this study are are to explore how the character of higher education lectures affect the students and to see the condition of the lecturers skill and personal character in educating and researching at the Department of Health Policy and Management (HPM) of Gadjah Mada University. From the literature review we can conclude that character is one of the aspects that can affect the student learning process. The lecturers character should affect the communication between lecturers and student. The lecturers character also can affect the student perception about the lecturers' credibility. Through that aspect, the lecturer character giving the impact to the students. The lecturer character should affect the students motivation and achievement. From the descriptive analysis result of online survey at HPM UGM, we can conclude that the lecturer have the confidence about their ability on researching, teaching and have strong personal character. The lecturers have the perception about themself, that they have strong ability on teaching, researching and have strong personal character.

This study may be driven in the university level, so we can see the whole lecturers capability at Gadjah Mada University. This research can reassure the university that they have the good performance of lecturer. This study also can magnify the lecturers problem to improve their ability on researching, teaching and to maintain their good character. So, the lecturer be confident to produce good graduates as a human resourses aset of Indonesia.

\section{References}

Barro, R. J. (2001). Human Capital and Growth. The American Economic Review, 12-17.

BERKOWITZ, M. W. (2004). Research-Based Character Education. THE ANNALS OF THE AMERICAN ACADEMY , 591.

Braxton, J. M. (2000). Faculty Teaching Skills and Their Influence on the College Student Departure Process. Journal of College Student Development , 215.

Center for Political Studies UI. (2014). Indonesian Legislative Profil. Jakarta: Center For Political Studies UI.

Chen, J.-Y. (2015). Virtue and the Scientist: Using Virtue Ethics. Sci Eng Ethics , 75-94.

Crosnoe, R. J. (2004). Intergenerational Bonding in School:The Behavioral and Contextual Correlates of Student-Teacher Relationships. Sociology of Education , 60-81.

Deci, R. M. (2000). The "What" and "Why" of Goal Pursuits: Human Needs and the Self-Determination ofBehavior. Psychological Inquiry, 227-268. 
DICKINSON, L. (1995). AUTONOMY AND MOTIVATION A LITERATURE REVIEW. System, 165-174.

Duffy, B. S. (2005). Comparing data from online and face-to-face surveys. International Journal of Market Research, 615-640.

Evans, J. R. (2005). The value of online surveys. Internet Research , 195-219.

Goldhaber, D. D., \& Brewer, D. J. (1996). Evaluating the Effect of Teacher Degree Level on Educational Performance. Evaluative/Feasibility .

Gorman, G. H. (1997). Some research perspectives on entrepreneurship education, enterprise education and education for small business management: a ten-year literature review. International Small Business Journal , 56.

Gough, R. (1997). Character is Everything: Promoting ethical excellence in sports. Wadsworth Publishing Company.

Gurin, P., Dey, E. L., Hurtado, S., \& Gurin, G. (2002). Diversity and higher education: Theory and impact on educational outcomes. Harvard Educational Review , 330-367.

Hanushek, E. A. (2007). Pay, Working Conditions, and Teacher Quality. The Future of Children, 69-86.

Hanushek, E. (1971). Teacher Characteristics and Gains in Student Achievement: Estimation Using Micro Data. The American Economic Review, 280-288.

Haring, D. G. (1946). ASPECTS OF PERSONAL CHARACTER IN JAP. The Far Eastern Quarterly (pre-1986), 12.

Hoy, W. K. (1967). Organizational Socialization: The Student Teacher and Pupil Control Ideology. The Journal of Educational Research, 153-155.

Hung-Lian, T., Lee, S., \& Koh, S. (2000). Educational gaps as perceived by IS educators: A survey of knowledge and skill requirements. The Journal of Computer Information Systems , 76.

Jong, A. d. (2006). Linking Employee Confidence to Performance: A Study of Self-Managing Service Teams. Journal of the Academy of Marketing Science, 576.

Jung, H.-S. T. (2003). The impact of public education expenditure on human capital, growth, and poverty in Tanzania and Zambia: a general equilibrium approach. Journal of Policy Modeling , 701-725.

LALL, J. S. (1993). TEACHER USE OF DESCRIPTIVE ANALYSIS DATA TO IMPLEMENT INTERVENTIONS TO DECREASE STUDENTS' PROBLEM BEHAVIORS. JOURNAL OF APPLIED BEHAVIOR ANALYSIS , 227-238.

Laudel, G. G. (2008). From Apprentice to Colleague: The Metamorphosis of Early Career Researchers. Higher Education, 387-406.

LIBORIUS, P. (2014). Who Is Worthy of Being Followed? The Impact of Leaders' Character and the Moderating Role of Followers' Personality. The Journal of Psychology, 347-385.

Luo, Y. (2008). A Strategic Analysis of Product Recalls: The Role of Moral Degradation and. Management and Organization Review , 183 - 196.

McAllister, M. S. (2013). Who is that masked educator? Deconstructing the teaching and learning processes of an innovative humanistic simulation technique. Nurse Education Today, 1453-1458.

Mitchell, S. A. (1996). Relationships Between Perceived Learning Environment and Intrinsic Motivation in Middle School Physical 
Education. JOURNAL OF TEACHING IN PHYSICAL EDUCATION , 369-383.

Prince, M. J., Felder, R. M., \& Brent, R. (2007). Does Faculty Research Improve Undergraduate Teaching? An Analysis of Existing and Potential Synergie. Journal of Engineering Education, 283.

Rowe, K. (2003). The Importance of Teacher Quality As A Key Determinant of Students' Experiences. Australian Council for Educational Research.

Rutjens, B. T. (2016). The Immoral Landscape? Scientists Are. PLOS ONE , 117.

Solomon, G. (1997). Does physical education affect character development in students? Journal of Physical Education, Recreation \& Dance, 38.

Summers, E. G., Matheson, J., \& Conry, R. (1983). The effect of personal, proffesional, and psychological attributes, and information seeking behavior on the use of information sources by educators. Journal of the American Society for Information Science, 75.

Thweatt, K. S. (1998). The impact of teacher immediacy and. Communication Education , 348-358.

Tinto, V. (1997). Classrooms as Communities: Exploring the Educational Character of Student Persistence. The Journal of Higher Education, 599623.

Trisnantoro, L. (2015). Prof. Young Scientist Forum. Yogyakarta: Graduate School of Gadjah Mada University.

Wang, M. C., Haertel, G. D., \& Walberg, H. J. (1994). What Helps Students Learn? Spotlight on Student Success. Educational Leadership , 74-79.

Wayne, A. J. (2003). Teacher Characteristics and Student Achievement Gains: A Review. Review of Educational Research, 89-122.

Webster, J. W. (2002). Analyzing the Past to Prepare for the Future: Writing a Literature Review. MIS Quarterly, xiii-xxiii.

WOODMAN, T. H. (2003). The relative impact of cognitive anxiety and selfconfidence upon sport performance: a meta-analysis. Journal of Sports Sciences , 443-457. 